\title{
Marketing Innovation: Study of Determinants of Innovation in the Design and Packaging of Goods and Services-Application to Portuguese Firms
}

\author{
Jacinta Moreira \\ Polytechnic Institute of Leiria \\ E-Mail: jacinta.moreira@ipleiria.pt \\ Maria José Silva \\ University of Beira Interior \\ E-Mail: msilva@ubi.pt \\ Jorge Simoes \\ Polytechnic of Tomar \\ E-Mail: jorgesimoess@gmail.com \\ Gastao Sousa \\ Maia Higher Institute \\ E-Mail: gsousa@docentes.ismai.pt
}

\begin{abstract}
The article analyzes factors stimulating firms' capacity for marketing innovation in terms of the design and packaging of goods and services. The data were obtained from the 4th Community Innovation Survey. The results of the logistic regression show that R\&D activities relating to internal R\&D activities; acquisition of machinery, equipment, and software; acquisition of other external knowledge; and carrying out other procedures - plus the factor of marketing activities-influence Portuguese firms' tendency to innovate in marketing.
\end{abstract}

Keywords: Marketing Innovation, Logit Model, CIS 


\section{INTRODUCTION}

Innovation is one of the most-important aspects of study in the area of social sciences and a widely explored topic nowadays. In addition, it contributes to company and market success, so lasting and sustainable economic growth can occur only if companies constantly make new products or services available. However, to understand innovation according to the logic of developing new goods for the market, it is essential to establish a relationship between innovation and marketing.

The aim of the article is to analyze the factors stimulating firms' capacity for marketing innovation, specifically in terms of the design and packaging of goods and services, centering analysis on the study of Portuguese industrial, commercial, and service firms. To do so, an entire theoretical framework of the subject of marketing innovation is considered, forming the basis for formulation of a set of hypotheses with a view to studying the factors referenced. To test the formulated hypotheses empirically, we use secondary data belonging to the 4th Community Survey of Innovation Activities. The data obtained will be subject to study through logistic regression models.

The article is structured as follows: In section two, based on the relevant literature on the subject of marketing innovation, a set of factors for study is proposed. In section three, the data and sample are defined, the hypotheses and variables are described, and the logistic regression model is presented, the analysis of which is contained in section four. The final section presents conclusions and principle implications of the study.

\section{LITERATURE REVIEW}

Innovation is regarded as one of the most-important aspects of business studies carried out at present, providing an important basis for understanding the evolution of the global economy and allowing the development of new products and services, or possible alterations to existing ones, thereby giving an effective response to market needs (Moreira, 2010).

The concept of marketing innovation can take numerous forms. According to CIS 4 (2005), marketing innovation consists of carrying out a new concept or a new marketing strategy that is different from the marketing methods present up till then in the firm, contemplating alterations to product design or packaging, product distribution and promotion, or pricing policy. Some authors define "marketing innovation" as innovation in marketing programs or methods, including the four Ps of marketing (Heunks, 1998; Shergill \& Nargundkar, 2005). Others consider innovation 
a new element of the marketing mix, capable of promoting new and evident advantages for companies (Harms \& Rohmann, 2002).

From the projects presented by the authors, it is inferred that the innovations constitute the basis for firm and market success (Harms \& Rohmann, 2002). The lasting and sustainable growth of the economy can take place only if the firms possess new products and services to offer constantly, for which investments in R\&D should be promoted. In short, the ability to generate a variety of new products and services successfully and find new forms of communicating and distributing them is vital for many organizations, since the sustainability of marketing activities is an essential factor for adapting to the market and the immediate changes, new technologies, and competitors' moves.

Marketing innovation is the result of a whole set of alterations introduced by the company, influenced by a vast set of internal and external factors. Aiming to analyze the process of marketing innovation in business and considering the literature review made, this study highlights factors related to technology, R\&D activities, and marketing activities. The factors to be studied in this investigation originate from those defined by the 4th Community Innovation Survey (CIS 4, 2005), also used in other studies (Frenz \& Ietto-Gillies, 2009; Guijarro \& Garcia, 2009; Harris \& Li, 2009; Hoffman, Parejo and Bessant, 1998; Kim \& Mauborgne, 1997; Maciariello, 2009; Masso \& Vahter, 2008; Millot, 2009; Romijn \& Albaladejo, 2002; Silva \& Leitão, 2009; Trienekens, Uffelen and Omta, 2008; Waarts, 2005; Youtie, 2006).

Technological capacity refers to knowledge, skills, and abilities needed to assimilate, adapt, or modify existing technologies or develop new technologies. Companies are consequently empowered in terms of skilled human resources and training (Hoffman, Parejo and Bessant, 1998). According to the CIS 4 (2005), training can occur at the internal or external level in firms, with the sole purpose of developing or introducing new products or new or improved processes in the market, therefore meeting the needs and desires of the target audiences.

In accordance with the above and according to Hofman et al. (1998) and Romijn and Albaladejo (2002), firms with greater technological capacity - that is, with highly skilled labor and higher levels of training - are more receptive to the absorption and reproduction of new knowledge, therefore showing a greater capacity for developing innovations. Also, the studies of Silva and Leitão (2009) and Silva (2003) confirm that the qualification of personnel, in terms of higher levels of education, exerts a positive and significant effect on the propensity for firms to innovate, while Guijarro et al. (2009) reported a lack of qualification and training of staff as a major barrier to 
innovation.

$\mathrm{R} \& \mathrm{D}$ and innovation require the design and development of new products, services, or processes — or the improvement of existing ones (CIS 4, 2005) —implying creativity of the firm and therefore connected to innovation in marketing. Considering the underlying 4th Community Innovation Survey, R\&D can integrate as follows: (i) carrying out internal activities of $\mathrm{R} \& \mathrm{D}$, (ii) external acquisition of $\mathrm{R} \& \mathrm{D}$, (iii) acquisition of machinery, equipment, and software, (iv) acquisition of other external knowledge, and (v) other procedures.

Given the performance of R\&D internally by the firm, creative works developed to increase the knowledge base as well as the use of knowledge of new products and processes are taken into account (CIS 4, 2005). According to Frenz and Ietto-Gillies (2009), Masso and Vahter (2008), and Silva et al. (2010), the greater the investment in such activities, the more likely the company will develop innovations.

The external acquisition of $R \& D$ considers the $R \& D$ activities equally creative with the purpose of enhancing the internal knowledge base within the company but executed externally by other public or private firms or institutions of R\&D (CIS 4, 2005). According to Freeman (1987), Nelson and Rosenberg (1993), and Chesbrough (2003), the external sources of knowledge play an important role in the innovation of the firm, even linked to its performance. In their works, Frenz and Ietto-Gillies (2009) and Harris and Li (2009) concluded that the external acquisition of R\&D is positively related to innovation in the firm.

According to Youtie (2006), any type of innovation, whether product, process, organization, or marketing, embodies in its implementation the acquisition of machinery, equipment, computers, or software. To the author, the acquisition of such goods is directly related to the benefits of innovation, which are visible through the quality and variety of goods, market share, increased capacity and production flexibility, as well as reduced time for product delivery and services. Also, Sanchez (1994) concluded that technological equipment exerts a major impact on innovations, including those that occur in industrial firms.

The acquisition of other external knowledge, specifically related to patent property rights, non-patented innovations, know-how, etc. (CIS 4, 2005), is an indicator with a strong influence on innovation, as mentioned by Millot (2009) and Silva et al. (2010). According to Millot (2009), this particular type of knowledge is positively related to innovation, and the association is particularly high in industrial sectors oriented towards knowledge-intensive and high technology.

Finally, the remaining procedures and techniques are still considered part of 
R\&D and innovation activities not previously addressed, but they are also at the service of product development and new or improved processes, possibly related to the experience of enhancement, skills, and the know-how of the firm.

The importance of marketing activities in the innovation process of the firm is evidenced in the work of Kim and Mauborgne (1997), Trienekens et al. (2008), Silva et al. (2010), and Chou (2009). Marketing activities are directed towards the introduction of new products or significantly improved products in the market, helping to differentiate the firm, emphasizing that the activities geared primarily through the study of the needs expressed in the market maintain a crucial role in the innovation business process.

\section{METHODOLOGY}

Methodology includes (i) characterization of the data, population, and sample used, (ii) definition of the hypotheses and variables of the study, and (iii) description of the data analysis method.

\section{Data, Population, and Sample}

The data used were taken from the 4th Community Innovation Survey, applied to Portuguese firms, under the supervision of EUROSTAT, collection having been directed by OCES (Science and Higher Education Observatory) in collaboration with INE (National Institute of Statistics). Data were gathered during the period of June to November 2005, although the period of observation covers the years 2002 to 2004 .

The population included in the analysis encompassed all of the industrial Portuguese firms involved in retail and service with at least 5 workers regarding their economic activities (CAE) (CAE - Rev.2.1), including a total of 22,749 firms registered in FGUE (INE's General File of Statistical Units).

The sample was constructed by INE based on the methodological specifications imposed by EUROSTAT, being made up of 6,243 Portuguese industrial, commercial, and service companies with at least 5 employees. Thus, Portuguese firms will be considered innovative in marketing if, during the period of 2002 to 2004, they introduced marketing innovation related to alterations in design or the packing of a good and/or service.

\section{Hypotheses and Variables}

Based on the literature review, seven hypotheses were formulated to be tested empirically: 
H1: Technological capacity is positively related to the firm's tendency to innovate in marketing in terms of design and packaging.

H2a: Carrying out internal R\&D activities is positively related to the firm's tendency to innovate in marketing in terms of design and packaging.

$\mathrm{H} 2 \mathrm{~b}$ : External acquisition of R\&D is positively related to the firm's tendency to innovate in marketing in terms of design and packaging.

$\mathrm{H} 2 \mathrm{c}$ : Acquisition of machinery, equipment, and software is positively related to the firm's tendency to innovate in terms of design and packaging.

$\mathrm{H} 2 \mathrm{~d}$ : Acquisition of other external knowledge is positively related to the firm's tendency to innovate in marketing in terms of design and marketing.

H2e: Fulfillment of technical procedures and preparations is positively related to the firm's tendency to innovate in marketing in terms of design and packaging.

H3: Firms that carry out marketing activities present greater tendency to innovate in marketing in terms of design and packaging than other firms.

Marketing innovation occurring in the sample firms is measured from the information gathered in terms of marketing innovation found in design and packaging of goods and services, considered the dependent variable. This dimension is presented as a dichotomous variable based on binary data: It assigns the value " 0 " for firms that did not innovate in marketing and the value " 1 " for those who innovated.

The independent variables were represented by technological capacity, R\&D activities, and marketing activities, as seen in Table 1.

This investigation only took into account whether or not the firm implemented some of these activities, assigning dichotomous variables based on binary data: the value " 1 " when performing innovation activities and the value " 0 " if otherwise. The same variables were used in empirical studies of Frenz and Ietto-Gillies (2009), Harris and Li (2009), Kim and Mauborgne (1997), Masso and Vahter (2008), Millot (2009), Silva and Leitão (2009), Trienekens et al. (2008), Silva et al. (2010), and Sanchez (1994).

The study used a control variable related to company characteristics: company size. To measure company size and following the classification proposed by the European Commission (EC, 2006), two variables were created: (1) small- and medium-sized company: 5 to 249 employees; (2) large company: 250 or more employees. 
Table 1 Independent Variables and Measures

\begin{tabular}{|c|c|c|c|c|}
\hline Concepts & Variables & $\begin{array}{l}\text { Attributed } \\
\text { Code }\end{array}$ & Measure & $\begin{array}{l}\text { Type/ } \\
\text { Coding }\end{array}$ \\
\hline $\begin{array}{l}\text { Technological } \\
\text { Capacity }\end{array}$ & Training & Form & $\begin{array}{l}1=\text { participates in } \\
\text { training activities } \\
0=\text { does not participate }\end{array}$ & Discrete/ Binary \\
\hline \multirow{5}{*}{$\begin{array}{c}\text { R\&D } \\
\text { Activities }\end{array}$} & Internal $R \& D$ activities & ID_i & $\begin{array}{l}1=\text { carried out } R \& D \\
\text { activities } \\
0=\text { did not carry out }\end{array}$ & Discrete/ Binary \\
\hline & $\begin{array}{l}\text { External acquisition of } \\
\text { R\&D }\end{array}$ & ID_e & $\begin{array}{l}1=\text { acquired } \mathrm{R} \& \mathrm{D} \\
0=\text { did not acquire }\end{array}$ & Discrete/ Binary \\
\hline & $\begin{array}{l}\text { Acquisition of } \\
\text { machinery, equipment, } \\
\text { and software }\end{array}$ & Aq_mes & $\begin{array}{l}1=\text { acquired machinery, } \\
\text { equipment, and software } \\
0=\text { did not acquire }\end{array}$ & Discrete/ Binary \\
\hline & $\begin{array}{l}\text { Acquisition of other } \\
\text { external knowledge }\end{array}$ & Aq_c & $\begin{array}{l}1=\text { acquired other } \\
\text { knowledge } \\
0=\text { did not acquire }\end{array}$ & Discrete/ Binary \\
\hline & Other procedures & Op & $\begin{array}{l}1=\text { carried out other } \\
\text { R\&D procedures } \\
0=\text { did not carry out }\end{array}$ & Discrete/ Binary \\
\hline $\begin{array}{l}\text { Marketing } \\
\text { Activities }\end{array}$ & $\begin{array}{l}\text { Development of } \\
\text { marketing activities }\end{array}$ & Act_mk & $\begin{array}{l}1=\text { developed } \\
\text { marketing activities } \\
0=\text { did not develop }\end{array}$ & Discrete/ Binary \\
\hline
\end{tabular}

\section{Method: Logistic Regression Model}

Faced with the complexity of the marketing innovation phenomenon, partly due to its being a recent and therefore little-explored subject and bearing in mind that a varied set of factors underlies its explanation, researchers deemed it necessary to explore the statistical relationship of a dependent variable in relation to more than one explanatory variable. From this assumption, we chose to use the Logistic Regression Model. It was also found that this model has been widely used in the empirical studies analyzed (Moreira, 2010; Masso \& Vahter, 2008; Silva \& Leitão, 2009), such as in the work of Moreira and Silva (2010), since it showed itself to be an appropriate analytical technique, including a categorical dependent variable and various independent variables as presented below:

$M I=\beta 0+\beta 1 F o r m+\beta 2 a I D \_i+\beta 2 b I D \_e+\beta 2 c A q \_m e s+\beta 2 d A q_{-} c+\beta 2 e O p+$ $\beta 3$ Act_mkg $+\beta 4$ Dim $+\varepsilon i$

Where $\mathrm{MI}=$ Marketing Innovation; $\varepsilon \mathrm{i}=$ residue; $\beta=$ coefficients; Form $=$ training; ID_i = R\&D internal activities; ID_e = external acquisition of R\&D; Aq_mes $=$ acquisition of machinery, equipment, and software; Aq_c $=$ acquisition of other 
external knowledge; Op = other procedures; = Act_mkg development of marketing activities; and Dim = dimension.

The next step was application of the logistic regression model to the data from the Community Innovation Survey, aiming to obtain results presented and discussed below.

\section{RESULTS AND DISCUSSION}

The logistic regression model aims to test empirically the effects of the aggregate independent variables of technological capacity, R\&D activities, and marketing activities on innovation in design and packaging, as presented in Table 2.

From analysis of the previous table and having used the Wald statistic as the test statistic, Model A reveals the existence of two variables that are not statistically significant at 5\%, specifically "technological capacity" and "external acquisition of R\&D." Faced with this situation, we excluded these variables and formed a new model (Model B) in which all estimates of the independent variable regression parameters are statistically significant at 5\%. The next step was inclusion of the control variable, company size, so as to test the robustness and consistency of the explanatory variables, obtaining Model C, which shows slightly better predictive capacity than Models A and B.

Hypothesis H1 associates the firm's capacity to innovate in design and packaging with technological capacity, this expressed in terms of participation in training activities. However, the variable does not present statistical significance in the model.

Hypothesis H2a relates the firm's capacity to innovate in design and packaging with carrying out internal R\&D activities. According to the results, the firm's carrying out of internal R\&D activities is found to have a positive influence on innovations made in the design and packaging of goods and services. It is found that firms carrying out this type of activity present an advantage for innovation and marketing of 1,443 over other firms, reinforcing therefore the results of the studies by Frenz and Ietto-Gillies (2009), Masso and Vahter (2008), Silva et al. (2010), and Moreira and Silva (2010).

Hypothesis H2b associates the firm's capacity to innovate in design and packaging with external acquisition of $R \& D$. The results of the model indicate that the explanatory variable of "external acquisition of R\&D" is without statistical significance, and the hypothesis in question is not confirmed empirically. 
Table 2 Logistic Regression of the Model of Innovation in Design and Packaging

\begin{tabular}{|c|c|c|c|c|c|c|c|c|c|}
\hline & \multicolumn{2}{|c|}{ Model A } & \multicolumn{2}{|c|}{ Model B } & \multicolumn{5}{|c|}{ Model C } \\
\hline & $\begin{array}{c}\text { Estimate } \\
\text { of } \\
\text { coefficients }\end{array}$ & $\begin{array}{c}\text { Test } \\
\text { value }\end{array}$ & $\begin{array}{c}\text { Estimate } \\
\text { of } \\
\text { coefficients }\end{array}$ & $\begin{array}{c}\text { Test } \\
\text { value }\end{array}$ & $\begin{array}{c}\text { Estimate } \\
\text { of } \\
\text { coefficients }\end{array}$ & $\begin{array}{c}\text { Stand. } \\
\text { Dev. }\end{array}$ & Wald & $\begin{array}{c}\text { Test } \\
\text { value }\end{array}$ & $\begin{array}{r}\text { Exp } \\
\text { (B) }\end{array}$ \\
\hline Form & $-0,025$ & 0,843 & & & & & & & \\
\hline ID_i & 0,427 & 0,000 & 0,422 & 0,000 & 0,367 & 0,118 & 9,698 & 0,002 & 1,443 \\
\hline ID_e & 0,001 & 0,992 & & & & & & & \\
\hline Aq_mes & 0,355 & 0,004 & 0,345 & 0,002 & 0,382 & 0,119 & 10,256 & 0,001 & 1,465 \\
\hline Aq_c & 0,449 & 0,000 & 0,446 & 0,000 & 0,348 & 0,126 & 7,562 & 0,006 & 1,416 \\
\hline Op & 0,482 & 0,000 & 0,479 & 0,000 & 0,455 & 0,117 & 15,102 & 0,000 & 1,576 \\
\hline Act_mkg & 1,426 & 0,000 & 1,422 & 0,000 & 1,420 & 0,112 & 159,624 & 0,000 & 4,137 \\
\hline Size & & & & & 0,145 & 0,134 & 1,163 & 0,281 & 1,156 \\
\hline Constant & $-2,437$ & 0,000 & $-2,439$ & 0,000 & $-2,576$ & 0,161 & 257,067 & 0,000 & 0,076 \\
\hline \multicolumn{10}{|l|}{$\begin{array}{l}\text { Quality of } \\
\text { model } \\
\text { adjustment }\end{array}$} \\
\hline $\begin{array}{l}\text { Correctly } \\
\text { predicted } \\
(\%)\end{array}$ & 83,7 & & 83,7 & & 83,9 & & & & \\
\hline Chi square & 762,439 & 0,000 & 762,400 & 0,000 & 620,811 & & & 0,000 & \\
\hline $\begin{array}{c}\text { Log } \\
\text { likelihood }\end{array}$ & 3628,433 & & 3628,472 & & 3197,985 & & & & \\
\hline $\begin{array}{l}\text { Number of } \\
\text { cases }\end{array}$ & 4637 & & 4637 & & 4114 & & & & \\
\hline
\end{tabular}

Hypothesis H2c states that acquisition of machinery, equipment, and software is positively related to the firm's tendency to innovate in marketing. The results of the model reveal that acquisition of these items has a positive and significant effect on the firm's capacity to innovate in marketing $(0,382)$, corroborating therefore the conclusions of Youtie (2006), Silva et al. (2010), and Moreira and Silva (2010). It is also found that firms that acquire machinery, equipment, and software present an advantage of 1,465 in developing marketing innovations related to design and packaging over companies that do not make this type of acquisition.

Hypothesis $\mathrm{H} 2 \mathrm{~d}$ aims to test the relationship between acquisition of other external knowledge, such as the purchase or license of patent rights and/or non-patented inventions, know-how, or other forms of knowledge, and the firm's capacity to innovate in design and packaging. The results of the model show firms that acquire external knowledge present advantages in innovating design and packaging over other firms $(0,348)$. This gives companies an advantage in innovation in terms of 
this dimension, which is 1,416 higher than firms that do not acquire this type of market input. Therefore, the studies by Millot (2009) and Silva et al. (2010) are corroborated.

The aim of Hypothesis H2e was to study empirically the relationship between carrying out technical procedures and preparations so as to facilitate implementation of new or significantly improved products or processes and the firm's tendency to innovate in the design and packaging of goods and services. The results of the model show that carrying out of these procedures by firms offers a positive and significant effect on marketing innovation $(0,455)$. It can be said that companies carrying out technical procedures and preparations are more likely to develop marketing innovations related to the design and packaging of goods and services than companies that do not engage in such activities and also have an advantage of 1,576 in developing innovative activities in terms of design and packaging over other companies.

The objective of Hypothesis $\mathrm{H} 3$ is to test empirically the effects of carrying out marketing activities - namely those related to market studies, market tests, and launch publicity — on the company's capacity to innovate in marketing in terms of design and packaging. The results of the model show that fulfillment of marketing activities by firms has a positive and significant effect on marketing innovation in terms of design and packaging $(1,420)$, showing an advantage of 4,137 in developing innovative activities over firms that do not carry out those activities. This also corroborates the results of the studies by Silva et al. (2010) and Moreira and Silva (2010).

\section{CONCLUSIONS}

The aim of the article was to analyze factors determining the innovative capacity for marketing in Portuguese firms, specifically concerning the design and packaging of goods and services. We considered, based on the theoretical review, a whole set of elements likely to affect marketing innovation and consequently companies' innovative capacity.

The results of the model indicate that firms carrying out marketing activities or R\&D internally, acquiring machinery, equipment, or software — or even other external knowledge or carrying out other types of procedures directed towards innovation - enjoy a greater tendency to innovate in marketing in terms of design and packaging than other firms. According to the results obtained, such practices present positive and significant effects in marketing innovation; therefore, the greater the financial investment in this type of activity, the greater the tendency for companies to 
innovate in marketing regarding the design and packaging of their goods and services.

The main contribution of this study lies in studying marketing innovation, in itself little explored in the literature, as well as the factors determining the capacity for marketing innovation in Portuguese companies, seeking in this way to increase understanding of the subject. The investigation proposed an empirical study based on a logit model with a view to analyzing the effects of the selected set of explanatory variables on the capacity for marketing innovation in Portuguese companies.

However, in carrying out this study, some limitations were detected, resulting, for example, from the restricted data obtained, as all results of CIS 4 were not available, which could lead to a new way of coding the variables. Nor was it possible to make a longitudinal study, considering the data from CIS 6, in order to assess evolutionary tendencies in the field of marketing innovation in the Portuguese context.

Therefore, to allow new empirical evidence about marketing innovation, it is pertinent to complement the study made with data from CIS 6 so as to allow analysis of marketing innovation over a longer period or even repeat the investigation based only on those data so as to obtain more up-to-date information and allow evaluation of evolutionary tendencies in marketing innovation developed by companies.

\section{REFERENCES}

Chesbrough, H. (2003). The era of open innovation. MIT Sloan Management Review, 44(3), 35-41.

Chou, H. (2009). The effect of market orientation intention and superiority on new product performance. The Journal of American Academy of Business, 14(2), 93-97.

CIS 4 (2005). $4^{\circ}$ Inquérito Comunitário à Inovação. Observatório da Ciência e do Ensino Superior, Lisboa: Ministério da Ciência, Tecnologia e Ensino Superior.

EC (2006). The New SME Definition - User guide and model declaration. Publications Business and Industry, European Commission.

Freeman, C. (1987). Technology Policy and Economic Performance: Lessons from Japan, London: Printer.

Frenz, M., Ietto-Gillies, G. (2009). The impact on innovation performance of different sources of knowledge: evidence from the UK community survey. Research Policy, 38(7), 1125-1135.

Guijarro, A., Garcia, D., Auken, H. (2009). Barriers to innovation among Spanish manufacturing SMEs. Journal of Small Business Management, 47(4), 465-488. 
Harms, F., Rohmann, S., Heinrich, M., Druener, M., Trommsdorff, V. (2002). Innovative marketing. Pharmaceuticals Policy and Laws, 5(5), 135-149.

Harris, R., Li, Q. (2009). Exporting, R\&D, and absorptive capacity in UK establishments. Oxford Economic Papers, 61(1), 74-103.

Heunks, F. (1998). Innovation, creativity and success. Small Business Economics, 10(3), 263-272.

Hoffman, K., Parejo, M., Bessant, J. (1998). Small firms, R\&D, technology and innovation in UK: a literature review. Technovation, 18(1), 39-55.

Kim, W., Mauborgne, R. (1997). Value innovation: The strategic logic of high growth. Harvard Business Review, 75(1), 102-112.

Maciariello, J. (2009). Marketing and innovation in the Drucker Management System. Journal of the Academy of Marketing Science, 37(1), 35-43.

Masso, J., Vahter, P. (2008). Technological innovation and productivity in late-transition Estonia: econometric evidence from innovation surveys. The European Journal of Development Research, 20(2), 240-261.

Millot, V. (2009). Trademarks as an Indicator of Product and Marketing Innovation. OECD Science, Technology and Industry Working Papers. 2009/06, OECD Publishing.

Moreira, J. (2010). Marketing Innovation - Study of the Determinants of Innovative Marketing Capability of Portuguese Companies. Doctoral Thesis in Management, University of Beira Interior, Covilhã, Portugal.

Moreira, J., Silva, M. J. (2010). Marketing Innovation and Innovative Capability of Marketing: Study of Portuguese Firms, Proceeding of European Conference on Innovation and Entrepreneurship - ECIE 2010, Edited by Alexandros Kakouris, National and Kapodistrian University of Athens, Greece.

Nelson, R., Rosenberg, N. (1993). Technical innovation and national systems. In Nelson, R. (Ed.), National Systems of Innovation: A Comparative Analysis (pp. 3-21). Oxford: Oxford University Press.

Romijn, H., Albaladejo, M. (2002). Determinants of innovation capability in small electronics and software firms in southeast England. Research Policy, 31(7), 1053-1067.

Sanchez, A. (1994). R\&D and firm size: some evidence from Spain. Technovation, 14(2), 63-69.

Shergill, G., Nargundkar, R. (2005). Market orientation, marketing innovation as performance drivers: extending the paradigm. Journal of Global Marketing, 19(1), 27-44. 
Silva, M. (2003). Business Innovative Capacity- study of factors that promote and limit the Portuguese industrial firms, Doctoral Thesis in Management, University of Beira Interior, Covilhã, Portugal.

Silva, M., Leitão, J. (2009). Cooperation in innovation practices among firms in Portugal: do external partners stimulate innovative advances? International Journal of Entrepreneurship and Small Business, 7(4), 391-403.

Silva, M., Sousa, G., Moreira, J. (2010). Actividades de Inovação e a Capacidade Inovadora das Empresas Portuguesas: Evidências Empíricas ao Nível do Sector dos Serviços, Proceedings of XX Luso - Spanish Conference on Management, 4-5 February, 2010, Instituto Politécnico de Setúbal, Portugal.

Trienekens, J., Uffelen, R., Omta, J. (2008). Assessment of innovation and performance in the fruit chain - the innovation-performance matrix. British Food Journal, 110(1), 98-127.

Waarts, E. (2005). Competition as an inspirational marketing tool. European Business Forum, 20(Winter), 38-41.

Youtie, J. (2006). Report shows threshold of skilled worker lags advance of technology. Manufacturing Business Technology, 24(3), 15-34. 
